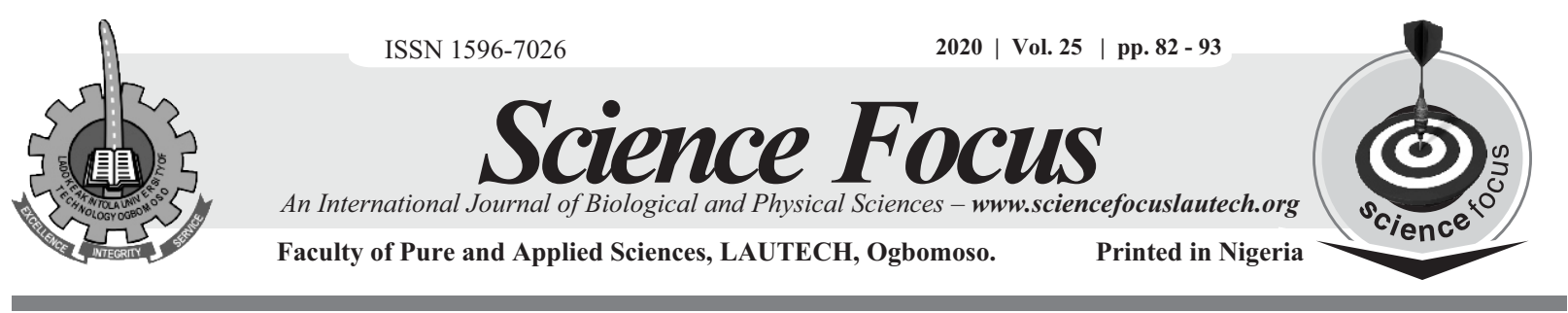

https://doi.org/10.36293/sfj.2020.0053

\title{
SOIL PHYSICAL PROPERTIES CHANGES AND PERFORMANCE OF MAIZE (Zea mays L.) UNDER DIFFERENT FERTILIZER TYPES IN SOUTHWEST NIGERIA
}

\author{
EWETOLA ESTHER ABOSEDE. ${ }^{1 *}$ YAKUBU, OLUWAKEMI ELIZABETH KUBURA ${ }^{1}$ \\ AND ISOLA JOHN OLUWASINA. ${ }^{2}$
}

\author{
${ }^{1}$ Department of Crop Production and Soil Science, Ladoke Akintola University of Technology Ogbomoso, \\ Nigeria \\ ${ }^{2}$ Department of Soil Science, Forest Research Institute of Nigeria, Ibadan, Nigeria
}

\begin{abstract}
Types of fertilizer applied may have different residual effects on soil and crop plants. Field studies were conducted during the 2015 and 2016 cropping seasons to compare the influence of different fertilizer types on soil physical properties and performance of maize (Zea mays L.). The experiment examined five fertilizer types; sole compost, Gliricidia sepium leaves, phospho-compost, integrated each applied at 5ton/ha, NPK 15:15:15 at $120 \mathrm{~kg} \mathrm{~N} / \mathrm{ha}$ and a control..The six treatments were arranged in a randomized complete block design with three replications. Data on soil physical properties, growth and yield of maize were determined at harvest. Integrated fertilizer reduced bulk density by 15 and $16 \%$ relative to the control and NPK respectively. In 2016, total porosity was increased by $26 \%$ under integrated approach compared with the control. Similarly, integrated fertilizer increased gravimetric moisture content by $113 \%$ compared with the control in 2016. Total water stable aggregates and total mean weight diameter were significantly higher under integrated with 12 and $15 \%$ respectively, over the control. Integrated recorded higher plant height, and grain yield compared with the control and other treatments. Therefore, for improvement in soil physical properties and yield of maize, integrated approach is recommended.
\end{abstract}

Keywords: Physical properties, compost, Gliricidia sepium leaves, NPK 15:15:15

Corresponding Author Email: eaewetola@lautech.edu.ng

\section{Introduction}

The soil physical condition constitutes a basic factor which affects crop growth and yield. It has been established that soil physical properties is highly correlated with crop production and soil fertility (Nnaji, 2009). The high yield of a crop can only be obtained under suitable physical conditions. The, high plants-nutrient- use efficiency can be achieved only when the physical nature of soils is improved because the physical properties of the soil are very important for agricultural production and sustainable use of soil (FAO, 2012). The stability of soil aggregates can curb surface sealing and soil erosion, improves water infiltration, and water holding capacity of the soil (Martínez-Blanco et al., 2013). Therefore, soil aggregation and its 
stability enhanced through increased soil organic matter can improve soil structure and productivity.

Intensively cropped soils are prone to deterioration in soil physical properties with the following resultant effects; reduced soil bulk density, decreased porosity, available water content and soil aggregation. Report has shown that the influence of intensive cropping and tillage practices on soil physical properties resulted in increased bulk density and reduced soil porosity when compared with uncultivated state of the soil (Mehdizale et al., 2013).

Sustaining cropping systems on a long term basis with the application of chemical fertilizers has been demonstrated to be grossly unhealthy for soils. It rather leads to a decline in soil organic matter content, acidification and physical degradation of soil, and consequently to increased soil erosion (Asadu and Nwajiaku, 2011; Getachew et al., 2014). Sole application of mineral fertilizer however has its limitations under intensive agriculture because it is often linked with nutrient imbalance and reduced crop yield (Ojeniyi, 2002; Adediran et al., 2005) The essential fertilizers are recurrently not available and unaffordable by most farmers due to high cost of imported materials, thereby posing a problem for its accessibility. Therefore the ecological and economic factors associated with the application of synthetic fertilizers to crops have necessitated the advocacy for the use of organic materials (Adediran et al., 2005, Ojeniyi, 2012).

Organic fertilizer application sustains cropping system and conserves the soil for future use through better nutrient recycling, improved soil structure and increased soil water - holding capacity (Lal, 2006). Composts as one of the organic fertilizer sources provides several inherent advantages such as enhanced soil fertility, improved pore spaces, permeability of soil, soil texture and increased moisture retention. Composts have also been known to stimulate biological activities, add nutrients to the soil bind and prevent its leaching, and encourage vigorous plant rooting system (Sarwar et al., 2008; Deneje and Lemlem, 2012).
Maize (Zea mays L.) is an important cereal crop in Nigeria which is mainly source of energy. The highly demanding effect of maize for nutrients from the soil prevents it from producing high yield on low fertile soils. Maize plant growth in response to compost application has been reported to produce taller plants on plot treated with compost compared to the control (Aziz et al., 2010; Ogbonna et al., 2012). The use of compost or prunings of Tithonia, Calliandra and Leucaena singly or combined with inorganic fertilizer have produced higher maize grain yield than control which was an indication that the organic materials improved nutrient use efficiency from inorganic fertilizer (Mugwe et al., 2007, 2009).

The application of inorganic or organic fertilizer alone did not bring soil improvement and sustainable increase in yield (Ojeniyi, 2002). However, the integrated fertilizer approach combines the positive attributes of organic and inorganic fertilizers, synchronizes nutrients release with the period of maximum need of the crop, ensures balance nutrition and availability of nutrients not included in inorganic fertilizers, fasten the release of organic nutrients through the decomposition of the nutrients (Ojeniyi, 2012).Thus, the sustainable management of the soil to prevent decrease in crop yields under continuous cropping has become major concern in agronomy research. Therefore, combined use of organic and mineral fertilizers has proven to be a sound soil fertility management strategy for improving soil fertility (Ojeniyi, 2012).

Consequently, there is a need to conduct further research on other techniques of restoring soil physical health prone to deterioration under intensive cropping so as to sustain crop yields in order to meet the ever increasing demand for food in Nigeria. Therefore, this studies were conducted to determine the influence of application of different fertilizers on soil physical properties and maize performance in Southwest Nigeria. 


\section{Materials and methods}

\section{Description of site}

Field studies were conducted at Ayedaade Area, located on latitude $\left(8^{\circ} 08^{\prime} 12.3^{\prime} \mathrm{N}\right)$ and longitude (4'12'12.6"E), Ogbomoso, Nigeria during 2015 and 2016 cropping seasons. Mean annual rainfall of the study area was $1000 \mathrm{~mm}$, while maximum and minimum annual temperatures were $30.5^{\circ} \mathrm{C}$ and $25.8^{\circ} \mathrm{C}$, respectively. The soil of the site was derived from sedimentary rocks and classified as an Alfisol (Udic Paleustalf) according to USDA classification (SSS, 2006). According to the local classification the soil belongs to Gambari series (Smyth and Montgomery, 1962).

\section{Field work}

The field was prepared manually with the aid of cutlass and hoe. Each plot (raised bed) measured $2.0 \mathrm{~m}$ by $2.25 \mathrm{~m}$ was cultivated with hoe to a height of $0.20 \mathrm{~m}$ and leveled with rake. The experiment was set up in a randomized complete block design with six treatments and three replications. The six treatments consisted of a control (no fertilizer or compost), Gliricidia sepium leaves and, phosphocompost, sole compost, integrated (sole compost + Gliricidia sepium leaves + NPK 15:15:15) all applied at 5 ton/ha and NPK 15:15:15 applied at $120 \mathrm{~kg}$ N/ha. Gliricidia sepium leaves (GL) was incorporated into the soil a week before sowing. Organic based fertilizers were applied at two weeks before sowing and NPK 15:15:15 was applied at two weeks after sowing. Each replicate was separated by $1 \mathrm{~m}$ and plots were $0.75 \mathrm{~m}$ apart. Maize seeds (Oba super 2), late maturing maize cultivar sourced from IITA, Ibadan were sown on July, 2015 and April, 2016 respectively. Maize seed were sown at a spacing of $75 \mathrm{~cm}$ x $25 \mathrm{~cm}$ to give a population density of 5333 plants/ha. Weeding was done manually as at when due on the field. At 10 weeks after sowing, data were collected on plant height, stover yield and grain yield (corrected to $13 \%$ moisture content).

\section{Soil sampling and analyses}

The pre- cropping soil samples were randomly collected at a depth of $0-15 \mathrm{~cm}$ depth from different points to form a representative sample from the field. These soils were bulked to form a composite sample, air dried and sieved with a 2 $\mathrm{mm}$ diameter mesh and were taken to the laboratory for determination of particle size and chemical analysis. Particle size analysis was done by hydrometer method (Gee and Or, 2002). Soil $\mathrm{pH}$ was determined with the $\mathrm{pH}$ meter using glass electrode in a soil: water ratio of $1: 1$. Organic carbon was determined by the WalkleyBlack procedure described by (Nelson and Sommers, 1986). Exchangeable cations (Ca, Mg, $\mathrm{K}$ and $\mathrm{Na}$ ) were extracted with $1 \mathrm{~N} \mathrm{NH4OAc}$ $(\mathrm{pH})$ at a soil: extracting solution ratio of 1 : 10 for $15 \mathrm{~min}$. The concentrations of $\mathrm{Ca}$ and $\mathrm{Mg}$ were read on the Atomic Absorption Spectrophotometer while those of $\mathrm{K}$ and $\mathrm{Na}$ were read on the Flame Photometer. Available phosphorus was determined using Bray II method (Bray and Kurtz, 1945) while Total nitrogen was determined by Macro-Kjeldahl method (Bremner, 1965)

The fertilizer samples were analysed for $\mathrm{C}, \mathrm{N}, \mathrm{P}$, $\mathrm{K}$, $\mathrm{Ca}$ and $\mathrm{Mg}$ according to Tel and Hagarty (1984) method.

\section{Physical properties}

Gravimetric moisture content was calculated as;

$$
\text { G. m. c }=\frac{\mathrm{M}_{1}-\mathrm{M}_{2}}{\mathrm{M}_{2}} \times 100
$$

Where $\mathrm{M}_{1}=$ Mass of wet soil

$\mathrm{M}_{2}=$ Mass of oven-dried

Bulk density was measured by the core method, as described by Blake and Hartage (1986)

Bulk density $=\frac{\text { soilmass oven dried }\left(\mathrm{g} / \mathrm{cm}^{3}\right)}{\text { volme of core }}$

Volume of soil sample $=$ volume of core; $\mathrm{r}=$ inner radius of the core, $\mathrm{h}=$ height of the core (cm) 
Total porosity of the soil was calculated from the values of bulk density $(\mathrm{Db})$ and particle density (Dp) of $2.65 \mathrm{Mgm}^{-3}$ ) using the following equation.

$$
\mathrm{Tp}=\left(1-\frac{\mathrm{Db}}{\mathrm{Dp}}\right) \times 100
$$

Where, $\mathrm{Tp}=$ Total porosity $\mathrm{Db}=$ Bulk density $\mathrm{Dp}=$ Particle density assumed $\left(2.65 \mathrm{Mg} \mathrm{m}^{-3}\right)$

\section{Macroporosity}

The macroporosity of the soil was determined as described by Danielson and Sutherland (1986). The undisturbed core sample was saturated for 48 hours in the laboratory. This was placed inside a tension table for desorption cycle. Macropore was determined at a suction of $60 \mathrm{~cm}$ and was calculated as;

$$
\mathrm{qw}=\frac{\mathrm{Ww}}{\mathrm{Vw}}
$$

Where qw - macroporosity,

$\mathrm{Ww}$ - the difference between wet and oven dry soil

$\mathrm{Vw}$ - the volume of soil.

Microporosity: Microporosity of the soil was determined by subtracting macro porosity from the total porosity.

Aggregate size distribution was determined by wet sieving technique according to Nimmo and Perkins (2002). To obtain different size fractions of water-stable aggregates, for the soil samples, $50 \mathrm{~g}$ of soil were placed in the top of a set of sieves with mesh sizes of $5 \mathrm{~mm}, 2 \mathrm{~mm}, 1 \mathrm{~mm}$, $0.25 \mathrm{~mm}$, and $0.045 \mathrm{~mm}$ from top to bottom. The sieve set was placed on the shock rack of a Yoder aggregates analyzer submerged in water, and shaken with amplitude of $3.8 \mathrm{~cm}$ and a frequency of $30 \mathrm{~min}^{-1}$ for duration of 30 mins. The size fraction at each sieve was then washed into a beaker of known mass and then dried and weighed.
Mean weight diameter (MWD) was calculated as

The mean weight diameter (MWD) was calculated as;

$\mathrm{MWD}=\sum \mathrm{x} i \mathrm{~W} i$

$$
\mathrm{i}=\mathrm{n}
$$

Where $\Sigma=$ Summation of the result of all the sieves

$\mathrm{xi}=$ the mean diameter of each size fraction $(\mathrm{mm})$

wi - the proportion of the total sample weight occurring in the corresponding size fraction

$\% \mathrm{WSA}=\frac{\mathrm{W} 2 \mathrm{i}-\mathrm{W} 3 \mathrm{i}}{\mathrm{W} 1 \mathrm{i}-\mathrm{W} 3 \mathrm{i}} \quad \mathrm{x} 100$

Where $\mathrm{W} 1 \mathrm{i}=$ Oven dried weight of soil sample $\mathrm{W} 2 \mathrm{i}=$ Oven dried weight of stable aggregate in each sieve fraction

$\mathrm{W} 3 \mathrm{i}=$ Oven dried weight of sand particles in each sieve fraction

\section{Statistical Analysis}

Data collected were subjected to Analysis of Variance using SAS procedure (SAS Institute, 2002) and treatment means were separated using the Duncan Multiple Range Test (DMRT) at 5\% level of probability. A regression analysis was run on soil organic carbon data with total water stable aggregate and total mean weight diameter of soil.

\section{Results and Discussion}

\section{Pre-cropping soil physical and chemical properties of the study site}

Initial characteristics of the soil from the study site are shown in Table 1.The $\mathrm{pH}$ of the soil was a slightly acidic (6.9). It was deficient in total $\mathrm{N}$ $\left(0.66 \mathrm{gkg}^{-1}\right)$, organic carbon $\left(6.4 \mathrm{gkg}^{-1}\right)$ and available $\mathrm{P}\left(1.66 \mathrm{mgkg}^{-1}\right)$ but sufficient in exchangeable bases with sandy loam texture. 
Table 1: Pre-cropping physical and chemical properties of the experimental site

\begin{tabular}{ll}
\hline Parameters & Values \\
\hline $\mathrm{pH}($ Water, $1: 2)$ & 6.90 \\
Total N (g/kg) & 0.66 \\
Available P (Bray-1) (mg/kg) & 1.66 \\
Organic carbon $(\mathrm{g} / \mathrm{kg})$ & 1.64 \\
Organic matter (g/kg) & 2.82 \\
& \\
Exchangeable bases (cmol/kg) & \\
$\mathrm{Ca}$ & 2.39 \\
$\mathrm{Mg}$ & 0.76 \\
$\mathrm{~K}$ & 0.33 \\
$\mathrm{Na}$ & 0.08 \\
& \\
Particle size (g/kg) & \\
Sand & 780 \\
Silt & 100 \\
Clay & 120 \\
Textural Class & Sandy \\
& loam \\
\hline
\end{tabular}

The selected chemical compositions of different fertilizers tested are shown in Table 2.The NPK 15:15:15 had higher concentrations of nitrogen, phosphorus and potassium while phosphocompost had the least nitrogen concentration. Sole compost had lower concentrations of phosphorus and potassium with higher Ca concentration. Glyricidia sepium leaves contain the higher concentrations of organic carbon and magnesium.

Table 2: Selected chemical composition of fertilizers tested

\begin{tabular}{|c|c|c|c|c|c|c|}
\hline $\begin{array}{c}\text { Fertilizer materials } \\
(\mathrm{g} / \mathrm{kg})\end{array}$ & $\mathbf{N}$ & $\mathbf{P}$ & Org. C & $\mathbf{C a}$ & $\mathbf{M g}$ & $\mathbf{K}$ \\
\hline Sole compost & 5.9 & 10.7 & 225.2 & 131.7 & 4.0 & 12.8 \\
\hline Phospho-compost & 5.2 & 25.6 & 251.8 & 83.3 & 3.7 & 13.8 \\
\hline Gliricidia sepium leaves & 32.0 & 27.0 & 910.0 & 11.4 & 4.3 & 27.14 \\
\hline N P K 15:15:15 & 150.0 & 150.0 & - & - & - & 150.0 \\
\hline
\end{tabular}




\section{Effects of different fertilizer types on selected soil physical properties}

\section{Gravimetric moisture content}

Soil gravimetric moisture content as influenced by different fertilizer types is presented in Table 3. Gravimetric moisture content was not influenced by fertilizer types in 2015, but integrated (INT) treatment had the highest moisture content. However in 2016, INT significantly increased moisture content compared with the control, NPK 15:15:15(NPK), Sole compost (SC), Gliricidia leaves (GL) and Phosphocompost (PC). The higher gravimetric moisture content observed on INT compared with the control, NPK and other fertilizer treatments at the end of the second year are consistent with the higher value of total porosity which was a reflection of increased organic carbon content on the plots. Therefore, the higher total porosity of INT plots revealed that the plots were able to retain more moisture than the other fertilizers treated plots as a result of improved soil structure due to higher organic carbon content. The result is in line with the findings of Zhao and Zhou (2011) that on a black soil, combine application of organic and inorganic fertilizer increased field moisture capacity by $44.8 \%$ compared with single application of inorganic fertilizer.

\section{Bulk density}

Fertilizer types effect on soil bulk density is presented in Table 3. Application of INT, PC, and GL significantly reduced soil bulk density compared with SC while control and NPK were similar to SC and other treatments in 2015. In 2016, INT significantly reduced soil bulk density relative to control and NPK, while SC and GL were statistically similar. Bulk density of soil decreased with corresponding increased in total porosity during both years of study on
INT fertilizer application compare with the control and other fertilizer types. The reduction in bulk density observed on INT plots could be attributed to the increased organic carbon content on INT as a result of combined application of organic and inorganic fertilizer which aided the microbial mineralization of the organic residue from GL, PC. This gave better aggregation and improved soil structure that reduced bulk density. This result corroborates the findings of Ellmer et al. (2000) that application of organic and chemical fertilizer influenced soil physical properties because they could change soil organic carbon content. Other studies have attributed soil bulk density reduction to higher organic matter content of the soil in the fertilizer and manure-amended plots (Hati et al., 2008; Bandyopadyhyay, et al., 2010).

\section{Total porosity, Microporosity and Macroporosity}

Total porosity as influenced by fertilizer types for 2015 and 2016 cropping seasons are shown in Table 3. GL, PC and NPK fertilizers had significantly higher total porosity compared with SC but were significantly different from the control in 2015 cropping season. Similarly in 2016 , total porosity was not different compare with the control. However, INT had significant higher total porosity compared with PC but was not different from other fertilizer types. The volume of micropores was significantly increased on SC treated soil than INT but not different from control and other treatments (Table 3). Data shown in Table 3 revealed that significant higher volume of macropores was observed on GL and NPK treated plots, while control, SC, PC, and INT were not different from each other (Table 3). However in 2016, NPK had significant higher macropores compared with INT while SC, GL and PC were not different from the control. 
Table 3: Effect of fertilizer types on selected soil physical properties

\begin{tabular}{lllllllllll}
\hline \multirow{2}{*}{ Treatment } & \multicolumn{2}{c}{$\begin{array}{c}\text { Gravimetric } \\
\text { Moisture }(\%)\end{array}$} & \multicolumn{2}{c}{$\begin{array}{c}\text { Bulk density } \\
\left(\mathrm{Mg} / \mathrm{M}^{3}\right)\end{array}$} & \multicolumn{2}{c}{$\begin{array}{c}\text { Total porosity } \\
(\%)\end{array}$} & \multicolumn{2}{c}{$\begin{array}{c}\text { Microporosity } \\
\left(\mathrm{M}^{3} / \mathrm{M}^{3}\right)\end{array}$} & \multicolumn{2}{c}{$\begin{array}{c}\text { Macroporosity } \\
\left(\mathrm{M}^{3} / \mathrm{M}^{3}\right)\end{array}$} \\
& 2015 & 2016 & 2015 & 2016 & 2015 & 2016 & 2015 & 2016 & 2015 & 2016 \\
\hline Control & $7.66 \mathrm{a}$ & $9.82 \mathrm{~b}$ & $1.54 \mathrm{ab}$ & $1.73 \mathrm{a}$ & $41.77 \mathrm{ab}$ & $35.00 \mathrm{ab}$ & $0.37 \mathrm{ab}$ & $0.24 \mathrm{a}$ & $0.41 \mathrm{ab}$ & $0.19 \mathrm{ab}$ \\
SC & $7.96 \mathrm{a}$ & $9.50 \mathrm{~b}$ & $1.62 \mathrm{a}$ & $1.66 \mathrm{ab}$ & $38.60 \mathrm{~b}$ & $37.00 \mathrm{ab}$ & $0.54 \mathrm{a}$ & $0.25 \mathrm{a}$ & $0.41 \mathrm{ab}$ & $0.17 \mathrm{ab}$ \\
GL & $8.60 \mathrm{a}$ & $10.19 \mathrm{~b}$ & $1.47 \mathrm{~b}$ & $1.68 \mathrm{ab}$ & $44.53 \mathrm{a}$ & $37.00 \mathrm{ab}$ & $0.36 \mathrm{ab}$ & $0.23 \mathrm{a}$ & $0.46 \mathrm{a}$ & $0.23 \mathrm{ab}$ \\
PC & $8.38 \mathrm{a}$ & $5.55 \mathrm{~b}$ & $1.47 \mathrm{~b}$ & $1.76 \mathrm{a}$ & $44.30 \mathrm{a}$ & $33.00 \mathrm{~b}$ & $0.37 \mathrm{ab}$ & $0.25 \mathrm{a}$ & $0.44 \mathrm{ab}$ & $0.19 \mathrm{ab}$ \\
INT & $8.18 \mathrm{a}$ & $20.93 \mathrm{a}$ & $1.42 \mathrm{~b}$ & $1.47 \mathrm{~b}$ & $46.43 \mathrm{a}$ & $44.00 \mathrm{a}$ & $0.30 \mathrm{~b}$ & $0.23 \mathrm{a}$ & $0.42 \mathrm{ab}$ & $0.15 \mathrm{~b}$ \\
NPK & $7.27 \mathrm{a}$ & $8.65 \mathrm{~b}$ & $1.51 \mathrm{ab}$ & $1.74 \mathrm{a}$ & $43.03 \mathrm{ab}$ & $34.00 \mathrm{ab}$ & $0.38 \mathrm{ab}$ & $0.23 \mathrm{a}$ & $0.45 \mathrm{a}$ & $0.23 \mathrm{a}$ \\
$15: 15: 15$ & & & & & & & & & & \\
\hline
\end{tabular}

Values with the same letter in the column are not statistically different at $5 \%$ level of probability using Duncan multiple range test; $\mathrm{SC}=$ Sole compost, $\mathrm{GL}=$ Gliricidia leaves, $\mathrm{PC}=$ Phosphocompost, $\mathrm{INT}=$ Integrated

\section{Aggregate stability}

Effects of fertilizer types on total water stable aggregate and total mean weight diameter is presented in Table 4. INT plots significantly increased the amount of water stable aggregates compared with the control. Total water stable aggregate was statistically similar among control, SC, GL, and PC fertilizer treatments. Mean weight diameter (MWD) ranged from 0.83 to $0.95 \mathrm{~mm}$, with the highest value of MDW observed in INT and lowest MWD in the control (Table 4). MWD was significantly greater on INT than control by $13 \%$ while NPK, SC, GL, and $\mathrm{PC}$ were not significantly different from the control. The understanding of organic matter or its fractions are basic to aggregation process and consequently, leads to protection of carbon within the aggregates against degradation. Total water stable aggregates and total mean weight diameter of the soil with higher values on INT fertilizer plots compared with the control plots can be ascribed to the higher value of organic carbon which enhanced soil aggregation and stabilization of aggregates to disintegration by water. The NPK 15:15:15 in the INT fertilizer must have aided the activities of soil microbes which assisted in decomposition and mineralization of the applied fertilizers. This result is in agreement with the findings that soil aggregation was markedly enhanced and therefore improved soil structure in a long term experiment when integrated nutrient with partial substitution of fertilizer $\mathrm{N}$ through organic material was applied (Su et al., 2006; Das, et al., 2016). Similarly, Hati et al. (2006) also reported that manure with mineral fertilizer application enhanced the stability of aggregates after 31 years of fertilizer application.

\section{Soil organic carbon}

The data on the effect of fertilizer types on_soil organic carbon (SOC) in 2016 is presented in Table 4. INT and SC significantly increased SOC compared with the control, GL and PC. NPK had significantly lower SOC than the control, GL, and PC. The higher value of soil organic carbon on INT and SC compared with PC and GL could be as result of the difference in the composition and biodegradability of the organic material. It has been observed that those materials with predominance of organic matter of low degradability will suffer lower organic carbon loss by microbial mineralization and consequently more organic carbon will remain in the soil (Remigio et al., 2019)

A linear relationship existed between water stable aggregates and SOC (Fig. 1). The $\mathrm{R}^{2}$ value $(0.471)$ revealed a positive but weak relationship. The relationship revealed that the stability of aggregate to disintegration is associated with the quantity of organic carbon present in the soil. 
Table 4: Effect of fertilizer types on total water stable aggregates (TWSA) and mean weight diameter (TMWD) in 2016 cropping season

\begin{tabular}{llll}
\hline Treatment & TWSA $(\mathrm{mm})$ & TMWD $(\mathrm{mm})$ & SOC $(\mathrm{g} / \mathrm{kg})$ \\
\hline Control & $0.54 \mathrm{~b}$ & $0.83 \mathrm{~b}$ & $6.00 \mathrm{~b}$ \\
Sole compost & $0.60 \mathrm{ab}$ & $0.93 \mathrm{ab}$ & $7.10 \mathrm{a}$ \\
Gliricidia sepium leaves & $0.61 \mathrm{ab}$ & $0.93 \mathrm{ab}$ & $6.50 \mathrm{~b}$ \\
Integrated & $0.62 \mathrm{a}$ & $0.95 \mathrm{a}$ & $7.90 \mathrm{a}$ \\
Phospho-compost & $0.61 \mathrm{ab}$ & $0.94 \mathrm{ab}$ & $6.30 \mathrm{~b}$ \\
N P K 15:15:15 & $0.57 \mathrm{ab}$ & $0.87 \mathrm{ab}$ & $5.70 \mathrm{c}$ \\
\hline
\end{tabular}

Values with the same letter in the column are not statistically different at $5 \%$ level of probability using Duncan multiple range test; $\mathrm{SC}=$ Sole compost, $\mathrm{GL}=$ Gliricidia leaves, $\mathrm{PC}=$ Phosphocompost, $\mathrm{INT}=$ Integrated

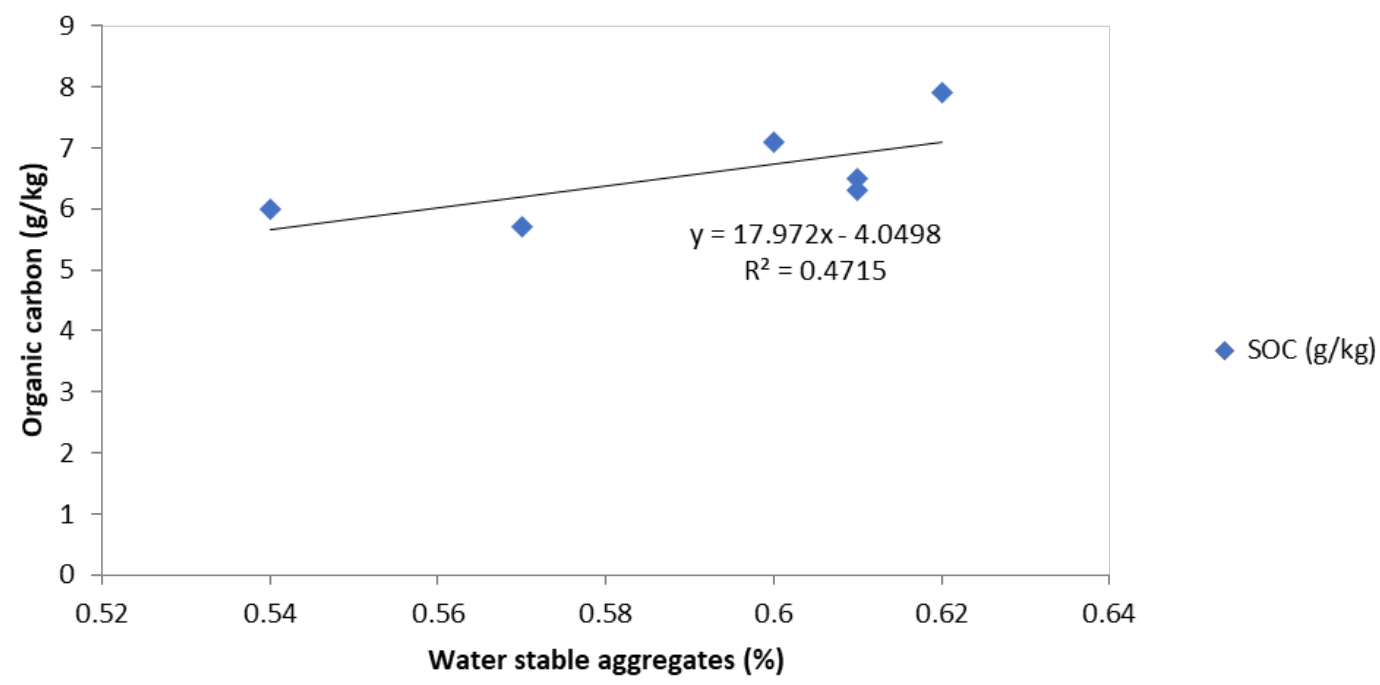

Fig. 1: Relationship between water stable aggregates and soil organic carbon

\section{Influence of fertilizer types on plant height and stover and grain yield of maize.}

The influence of fertilizer types on plant height and yield of maize in 2015 and 2016 cropping seasons are shown in Table 5. INT fertilizer produced significantly taller maize plant compared with the control and GL in 2015, while SC, PC and NPK fertilizer were not different from INT or the control. In 2016, maize plant heights were statistically similar among fertilizer types. Relative to the control in 2015, INT and NPK fertilizers applied increased stover yield of maize by $118 \%$ and $135 \%$, respectively. Similarly in 2016, stover yield of maize increased on INT and NPK compared with the control, SC and GL. In 2015 cropping season, different fertilizer types had no significant effect on maize grain yield. However, in 2016, INT plots produced significantly higher grain yield compared with the control, NPK, SC, GL, and PC whilst NPK was not different from the control and fertilizer types. Integrated treatment has shown to produce taller plants than the control. This could be attributed to the improved soil physical condition that promoted higher nutrients availability from the combined application of both organic and NPK 15:15:15 which aided release of the nutrient to the maize plant. The result during the two years of study revealed that stover yields on INT plot was comparable to NPK plots which could be 
ascribed to ease of mineralization of sole application of NPK and its inclusion in INT that enhanced luxuriant growth to produce higher stover yield than the control and other fertilizer types. The higher grain yield on INT among fertilizer types could be related to the higher organic carbon which translated to the improved soil physical condition, better growth and higher grain yield on INT fertilizer management. The application of both organic and inorganic fertilizer under INT had complementary effect that culminated to increased maize yield. The result is in agreement with Deneje and Lemlem (2012) who reported that application of organic fertilizer improved crop growth by supplying plant nutrients and improved physical and chemical properties of the soil thereby providing a better environment for root development by improving the soil structure. Other studies indicated that combined application of organic and inorganic fertilizers produced better plant height of maize than sole application of mineral fertilizer (Ayoola et al., 2009; Afolabi, et al., 2017)

Table 5: Effect of fertilizer types on plant height, stover and grain yield of maize

\begin{tabular}{|c|c|c|c|c|c|c|}
\hline \multirow{3}{*}{ Treatment } & \multicolumn{4}{|c|}{ Plant height $(\mathrm{cm})$} & \multirow{2}{*}{\multicolumn{2}{|c|}{ Grain yield (ton/ha) }} \\
\hline & \multirow[b]{2}{*}{2015} & \multirow[b]{2}{*}{2016} & \multicolumn{2}{|c|}{ Stover yield } & & \\
\hline & & & 2015 & 2016 & 2015 & 2016 \\
\hline Control & $100.57 b$ & $112.20 \mathrm{a}$ & $6.50 \mathrm{c}$ & $10.10 \mathrm{~b}$ & $1.20 \mathrm{a}$ & $2.60 \mathrm{~b}$ \\
\hline $\mathrm{SC}$ & $144.23 \mathrm{ab}$ & $132.20 \mathrm{a}$ & $12.40 \mathrm{ab}$ & $9.30 \mathrm{~b}$ & $1.80 \mathrm{a}$ & $2.80 \mathrm{~b}$ \\
\hline GL & $137.98 \mathrm{ab}$ & $131.70 \mathrm{a}$ & $11.30 \mathrm{ab}$ & $9.07 \mathrm{~b}$ & $1.50 \mathrm{a}$ & $3.10 \mathrm{~b}$ \\
\hline $\mathrm{PC}$ & $131.37 \mathrm{ab}$ & $138.50 \mathrm{a}$ & $10.70 \mathrm{ab}$ & $11.23 \mathrm{ab}$ & $1.60 \mathrm{a}$ & $3.50 \mathrm{~b}$ \\
\hline INT & $155.73 a$ & $136.70 \mathrm{a}$ & $14.20 \mathrm{a}$ & $16.27 \mathrm{a}$ & $1.70 \mathrm{a}$ & $5.90 \mathrm{a}$ \\
\hline $\begin{array}{l}\text { NPK } \\
15: 15: 15\end{array}$ & $127.87 \mathrm{ab}$ & $128.60 \mathrm{a}$ & $15.40 \mathrm{a}$ & $16.00 \mathrm{a}$ & $1.40 \mathrm{a}$ & $0.49 \mathrm{ab}$ \\
\hline
\end{tabular}

Values with the same letter in the column are not statistically different at $5 \%$ level of probability using Duncan multiple range test; $\mathrm{SC}=$ Sole compost, $\mathrm{GL}=$ Gliricidia leaves, $\mathrm{PC}=$ Phosphocompost, $\mathrm{INT}=$ Integrated

\section{Conclusion}

Application of integrated fertilizer approach reduced bulk density, increased total porosity, moisture content, soil organic carbon, soil aggregation, stover and grain yield of maize

\section{References}

Adediran, J. A., Taiwo, L. B., Akande, M. O., Sobulo, R. A. and Idowu, O. J. (2005). Application of organic and inorganic fertilizer for sustainable maize and cowpea yields in Nigeria. Journal of Plant Nutrition, 27(7), 11631181.

Asadu, C. L. A. and Nwajiaku, I. M. (2011). The effects of four ratios of organic to inorganic manures on soil physico-chemical properties and compared with the control and other fertilizer types. Therefore, the use of integrated fertilizer approach is recommended for improvement of soil physical properties and sustainability of crop production in South west Nigeria

maize yield. Agro-Science Technology Engineering and Mechanization Journal, 10 (2): 1-6.

Afolabi, S. G., Odofin, A. J., Adeboye, M. K. A., Samson, V. M. and Popoola, A.F. (2017). Comparative effects of sole and combined applications of poultry manure and inorganic fertilizers on soil quality and maize performance at Minna and Anyigba, Nigeria. Nigerian Journal of Soil Science, 27: 82-90. 
Ayoola, O.T. and Makinde, E. A. (2009). Maize growth yields and soil nutrients changes with Nenriched organic fertilizers. African Journal of Food Agriculture Nutrition and Development 9 (1): 580-592.

Aziz, T., Ullah, S., Sattar, A., Nasim, M., Farooq, M. and Khan, M. M. (2010). Nutrient availability and maize (Zea mays L.) Growth in Soil Amended with Organic Manures. International Journal of Agriculture and Biology, 12: 621-624.

Blake, G. R., Hartage, H. (1986). Bulk density In: A.K. Klute (ed.) methods of soil Analysis Part 1Physical and Mineralogical Methods. Madison, WI. American Society of Agronomy Soil Science Society of American. 363-375.

Bandyopadyhyay, K. K., Misra, A. K., Ghosh, P. K. and Hati, K.M. (2010). Effect of integrated use of farmyard manure and chemical fertilizers on soil physical properties and productivity of soybean. Soil Tillage and Research, 110: 115125.

Bray, R.H., and Kurtz, L.T. (1945). Determination of total organic and available forms of phosphorus in soils. Soil Science 59: $39-45$.

Bremner, J.M. (1965). Inorganic forms of nitrogen. In: C. A. Black, D. D. Evans J. L. White, L. E. Ensminger F.E Clark (Eds.). Methods of soil analysis part 2. Agronomy Monograph 9 American Society of Agronomy, Madison, pp. 117-123.

Danielson, R. E. and Sutherland, P. L. (1986). Porosity: In: A. Klute (eds.) Methods. Madison, American Society of Agronomy, USA, pp. 443460.

Das, B., Chakraborty, D., Singh, V. K., Ahmed, M., Singh, A. K. and Barman, A. (2016). Evaluating fertilization effects on soil physical properties using a soil quality index in an intensive rice-wheat cropping system. Pedosphere, 26(6): 887-894.
Dejene, M. and Lemlem, M. (2012). Integrated Agronomic Crop Managements to Improve Teff Productivity under Terminal Drought, Water Stress, In Tech Open Science, London, UK,

Ellmer, F., Peschke, H., Kohn, W., Chmielewski, F.M. and Baumecker, M. (2000). Tillage and fertilizing effects on sandy soils. Review and selected results of long-term experiments at Humboldt-University Berlin. Journal of Plant Nutrition and Soil Science 163: 267-272.

Gee, G.W. and Or, J.W. (2002).Particle size analysis. In: A. Klute (Eds.). Methods of Soil Analysis, Part 1: Physical and Mineralogical Methods. SSSA, Inc. Madison, WI. 383- 412.

Getachew, A., van Beek, C. and Michael, I. B. (2014). Influence of integrated soil fertility management in wheat and teff productivity and soil chemical properties in the highland tropical environment. Journal Soil Sciences Plant Nutrition, vol. 14, pp. 532-545.

International Institute for Tropical Agriculture (1982). Selected methods for soil and plant analysis. International Institute of Tropical Agriculture, Ibadan, Nigeria. International Institute for Tropical Agriculture Manual Series, No.7, Pp 53-56.

Hati, K. M., Swarup, A., Dwivedi, A. K., Misra, A. K. and Bandyopadyhyay, K. K. (2007). Changes in soil physical properties and organic carbon status at the topsoil horizon of a vertisol of central India after 28 years of continuous cropping, fertilization and manuring. Agriculture Ecosystem and Environment, 119:127- 134.

Kang, B.T. and Juo, A.S.R. (1980). Management of low activity clay soils in tropical Africa for food crop production. In Terry E. R. K. A. Oduro and F. Caveness (eds.) Tropical root crops: Research strategies for the 1980s. Ottawa, Ontario, International Development Research Centre: 129-133.

Karami, A., Homaee, M., Afzalinia, S., Ruhipour, H. and Basirat, S. (2012). Organic resource management: impacts on soil aggregate 
stability and other physico-chemical properties. Agriculture Ecosystem and Environment, 148: 22-28.

Lal, R. (2006). Enhancing crop yields in developing countries through restoration of soil organic carbon pool in agricultural lands. Land Degradation and Development. 17:197-206.

Leroy, B.L., Bommele, L., Reheul, D., Moens, M. and De Neve, S. (2007). The application of vegetable, fruit and garden waste (VFG) compost in addition to cattle slurry in a silage maize monoculture: Effects on soil fauna and yield. European Journal of Soil Biology, 43: 91-100.

Lombin, L.G., Adepetu, J. A. and Ayotade, K. A. (1991). Organic fertilizer in the Nigerian agriculture: Present and future FertilizerProcument and Distribution Division, Abuja. : 146-162.

Martínez-Blanco, J., Lazcano, C., Christensen, T. H., Munoz, P., Rieradevall, J., Møller, J., Antón, A. and Boldrin, A. (2013). Compost benefits for agriculture evaluated by life cycle assessment. A review: Agronomy for Sustainable Development, 33(4): 721-732.

Mehdizale, M., Darbandi, E. I. Naseri-Rad, H. and Tobeh, A. (2013). Growth and yield of tomato (Lycopersicon esculentum Mill.) as influenced by different organic fertilizers. International Journal of Agronomy and Plant Production, 4 (4): 734-738.

Mugwe, J. Mugendi, D., Kungu, J. and Mucheru-Muna, M. (2007). Effect of plant biomass, manure and inorganic fertilizer on maize yield in the central highlands of Kenya. African Crop Science Journal, 15 (3): 111 - 126

Mugwe, J., Mugendi, D., Kungu, J. and Monicah-Mucheru, M. (2009). Maize yields response to application of organic and inorganic input under on-station and on-farm experiments in central Kenya. Experimental Agriculture, 45: 47-59.
Nelson, D.W. and Sommers, L. E. (1982).Total organic carbon and organic matter. In: (Eds.) Methods of soil analysis part 2: Agronomy Monograph 9: ASA, Madison WI: pp.539-594.

Nimmo, J. R. and Perkins, K. S. (2002). Aggregate stability and size distribution. In: J.H. Dane and G. C. Topps (eds.), Methods of Soil Analysis: Part 4, Physical methods. SSSA, Inc., Madison, WI, pp. 238-317.

Nnaji, G.U. (2009). Changes in physical properties of soil under cassava (Manihot esculenta Crantz) monocropping and organic waste amendments. Natural and Applied Science Journal 10(1):12-17.

Odu, C.T.I, Babalola, O., Udo, E. J., Ogunkunle, A. O., Bakare, T. A. and Adeoye, G.O. (1986).Laboratory manual for agronomy studies in soil, plant and microbiology. Department of Agronomy, University of Ibadan, Nigeria, 83 pages .

Ogbonna, D.N., Isirimah, N.O. and Princewill, E.(2012). Effect of organic waste compost and microbial activity on the growth of maize in the ultisol in Port Harcourt, Nigeria. African Journal of Biotechnology, 11: 12546-12554.

Ojeniyi, S.O. (2002).Tropical Soil Management and Natural Resource and Environment, Adeniran Com. Press, Oke -Ado, Ibadan.Nigeria,30 pages.

Ojeniyi, S.O. (2012). Advance in integrated nutrient management for crop in Nigeria. Journal of Technological Research, 7:39-43.

Parr, J.F., Papendick, R.I. and Calacicco, C. (1986).Recycling of Organic wastes for sustainable agriculture. Horticulture 1:115-130. Paradelo, R., Eden, M., Martinez, I., Keller, T. and Houot, S. (2019). Soil physical of a Luvisol developed on loss after 15 years of ammendment with compost. Soil and Tillage Research, 191: 207- 215 .

Sarwar, G., Hussain, N., Schmeisky, H., Muhammad, S., Ibrahim, M. and Safdar, E. (2008). Improvement of soil physical and 
chemical properties with compost application in Rice-wheat cropping system. Pakistan Journal of Botany, 40(1): 275-282.

SAS Institute (2002). Statistical Analysis System "SAS / STAT" User's Guide, Version 6,Fourth edition; Vol. 1. The SAS Institute Inc., Gary, N.C

Smyth, A. J. and Montgomery, R. F. (1962). Soils and Land Use in Central Western Nigeria. Government Printer, Ibadan, 265 pages.

Su, Y. Z., Wang, F., Suo, D. R., Zhang, Z. H. and $\mathrm{Du}, \mathrm{M}$.W. (2006). Long term effects of fertilizer and manure application on soil-carbon sequestration and soil fertility under the wheatwheat-maize cropping system in northwest China. Nutrient Cycling Agroecosystem.75: 285-295.
Soil Survey Staff, (2014). Soil survey manual agricultural handbook 18. Soil Conservation Service, Washington D.C., 372 pages.

Tel, D.A. and Hagarty, M.(Eds.), 1984. International Institute of Tropical Agriculture,University of Guelp, Ibadan, Nigeria, Guelph, Ontario, Canada, 277 pages.

Zhao, J. and Zhou, L. (2011). Combined application of organic and inorganic fertilizers on black soil fertility and maize yield. Journal of Northeast Agricultural University (English Edition) 18 (2): 24-29.

Zheljazkov, V. D. and Warman, P. R. (2004). Source-separated municipal solid waste compost application to Swiss chard and Basil. Journal of Environmental Quality, 33: 542-552. 